\title{
The Effect of Exchange Rate Fluctuation on the Performance of Manufacturing Firms: An Empirical Evidence from Ghana
}

\author{
Emmanuel Buabeng (10 ${ }^{1} \quad$ Enock Kojo Ayesu (1) ${ }^{2}$ Opoku Adabor (i] $^{3}$
}

Received: 07.11.2019; Revised: 23.12.2019; Accepted: 29.12.2019

\begin{abstract}
This study examines the effect of exchange rate fluctuations on the performance of manufacturing firms in Ghana for the period 1990 to 2018. The study uses the bounds test approach to cointegration within the framework of autoregressive distributed lags model as the estimation strategy. The results reveal that exchange rate and monetary policy rate has a negative and significant relationship with manufacturing firm performance. It was also found that inflation, trade openness, and investment have significant positive relation with manufacturing firm performance in Ghana. Based on the negative and significant relationship with exchange rate and manufacturing firm performance, it is recommended that government and private partnership should ensure effective management of the exchange rate fluctuation and also encourage manufacturing firms to patronize locally made capital goods for their production in the face of a depreciating exchange rate. Further, the study recommends that monetary authorities should reduce interest rate to increase investment by firms. This will enhance manufacturing firms' performance.
\end{abstract}

JEL codes: D51, D20, C22

Keywords: Exchange rate, manufacturing firms' performance, ARDL, Ghana

\section{Introduction}

The effect of exchange rate fluctuation on economic growth is well recognized. However, maintaining exchange rate stability overtime has been the goal (challenge) of

\footnotetext{
${ }^{1}$ Department of Economics, Kwame Nkrumah University of Science and Technology, Kumasi, Ghana. (e-mail: ebuabeng79@gmail.com)

2 Corresponding Author Department of Economics, Kwame Nkrumah University of Science and Technology, Kumasi, Ghana. (e-mail: ayesu.enock@yahoo.com).

3 Department of Economics, Kwame Nkrumah University of Science and Technology, Kumasi, Ghana. (e-mail: adaboropoku@gmail.com)
}

most developed and developing countries. Exchange rate is a significant macroeconomic variable because its depreciation or appreciation has negative repercussions on all the sectors of the economy especially the manufacturing sector (Odili, 2014; Aizenman \& Marion, 1999). Through international trade among countries, economies have experienced periods of exchange rate fluctuations, slower growth among others (Todaro \& Smith, 2008; Bahmani-Oskooee \& Miteza, 2003) and this has exposed many developing countries to periods of imbalances. Notwithstanding, exchange rate 
fluctuations does not only affect economic growth but also the performance of firms. For instance, exchange rate depreciation increases the cost of imported capital goods for manufacturing firms and this results to a fall in domestic investment among others. Therefore, the manufacturing sector(firms) play a vital role in modern economy worldwide and has the potential benefits that are key for economic transformation (Ayobami, 2019) and Ghana is no exception. Specifically, in Ghana the manufacturing sector continues to play a vital role in the economy and contributed averagely 7 percent to Gross Domestic product between the year 2006 to 2016 (Ghana Statistical Service, 2017). They also contribute to employment creation, corporate social responsibilities, foreign exchange earnings, promote the growth of investment, increasing productivity among others. And this lead to the improvement in the socio-economic welfare of the individual in the country. Notwithstanding the contribution of the manufacturing sector(firm) to the growth of the country and the improvement in the socio-economic welfare of the populace, one key problem faced by the manufacturing sector in Ghana is exchange rate fluctuation. This is so because the manufacturing sector depends highly on imported capital goods or raw materials to undertake their production activities hence any fluctuations in the exchange rate has negative repercussion on the growth (performance) of the sector among others.

However, in an economy that is driven by importation of capital goods and raw materials to feed it manufacturing sectors, the sector has been plagued by numerous setbacks as a result of exchange rate fluctuations making them less competitive locally and globally. Thus exchange rate fluctuations has led to the collapse of most manufacturing firms and also created an atmosphere of macroeconomic uncertainty which leads to a reduction in firms' profit, reduces employment levels as well as investment levels and also decreases in firm productivity.

In spite of the above empirically, (see for instance Ofori et al., 2018; Alagidede \& Ibrahim, 2017; Salifu et al., 2007; Nyarko et al., 2011; Mensah et al., 2013; Insah \& Chiaraah, 2013; Bhattarai \& Armah, 2005; Frimpong \& Adam, 2010; Kyereboah-Coleman \& Agyire-Tettey, 2008; Opoku-Afari et al., 2004; Gyimah-Brempon \& Gyapong, 1993), very little is known on the effect of exchange rate fluctuations on manufacturing firms' performance in Ghana. Notwithstanding, there is evidence of the effect of exchange rate fluctuations on economic growth, capital inflows, trade balance, employment and growth in the empirical literature (see for instance Elbadawi et al., 2008; Umaru et al., 2018; Alagidede \& Ibrahim, 2017; Kenneth et al., 2016; Mensah et al., 2013; Nyarko et al., 2011; Salifu et al., 2007; Bhattarai \& Armah, 2005; Opoku-Afari et al., 2004; Gyimah-Brempon \& Gyapong, 1993). However, to the best of our knowledge, we are aware of only two empirical studies that investigated the effect of exchange rate fluctuations (see; Boateng, 2019; Abdul-Mumuni, 2019) on manufacturing firms' performance in Ghana. Specifically, Boateng (2019) focused on manufacturing sector in terms of financial performance and used return on assets and equity as a measure for manufacturing sectors performance whereas Abdul-Mumuni (2019) used manufacturing sectors percentage of Gross Domestic product (GDP) as a measure of manufacturing sectors performance.

In this regard, the present study differs from studies by (see Boateng, 2019; AbdulMumuni, 2019) significantly on the effect of exchange rate fluctuations on the performance of manufacturing sectors in Ghana for at least a number of reasons and make at least two significant contributions. Firstly, we add to the scanty literature on the nexus between exchange rate fluctuation and manufacturing sectors performance in Ghana. Secondly, the present study uses a relatively 
current and larger sample period from 1990 to 2018 as compared to that of AbdulMumuni (2019) and Boateng (2019) that used 1986 to 2013 and 2009 to 2017. Thirdly we focus on different controls compared to the studies by (Abdul-Mumuni, 2019; Boateng, 2019) which includes: exchange rate, monetary policy rate, trade openness, and investment. We pay attention to the manufacturing firms with the reasons that, (i) averagely they contribute 7 percent to Gross Domestic product in Ghana (Ghana Statistical Service, 2017), (ii) exchange rate fluctuations affect manufacturing sectors mostly in all economies as they contribute largely to employment creation, foreign exchange creation, promoting of investment and over all to the socio-economic welfare of the populace, (iii) exchange rate fluctuations affect adversely the ability of manufacturing sectors to import capital goods and raw materials leading to a reduction in performance, (iv) exchange rate fluctuation affects the income and profitability of firms thereby reducing their contribution in terms of GDP, (v) and exchange rate fluctuations in general contribute to some extent the higher level of unemployment as manufacturing sectors turn to lay workers off from their duties.

The rest of the paper is organized as follows. What follows is the related literature on the effect of exchange rate on manufacturing firms' performance. In addition, the estimation technique and data used is discussed and finally the results discussions, conclusion and policy recommendation.

\section{Literature Review}

Empirically, a number of studies have examined exchange rate effect on manufacturing firm's performance in developed and developing countries. Ayobami (2019) examined the effect of exchange rate fluctuation on the performance of manufacturing firms in Nigeria for the period 1981 to 2016. The study uses data from the world development indicators of the world bank and statistical bulletin of the central bank of Nigeria and applies the auto-regressive distributed lag model as the estimation strategy. The study reveals that the growth of manufacturing firms' in Nigeria is positively related with exchange rate fluctuations but is insignificant.

Elbadawi et al. (2008) investigate the effect of foreign aid, real exchange rate on economic growth for the period 1970 to 2014 for developed and developing countries. Data from the world development indicators, and International Financial Statistics was used. The study employs the pooled mean grouped as the estimation technique. The results from the study reveal that foreign aid affect economic growth positively and significantly. In addition, the study finds that real exchange rate overvaluation reduces growth. Similarly, Williams (2018) examine the impact of exchange rate fluctuations on the performance of some selected listed firms in Nigeria for the period 2012 to 2016. The study employs the ordinary least square regression as the estimation technique. The study reveals that exchange rate has a positive and significant effect on firms' performance. In addition, the results from the study also show that there is a positive and significant association between inflation and firms performance.

Umaru et al. (2018) investigate the effect of exchange rate volatility on economic growth among selected English speaking (that included Ghana, Gambia, Nigeria, and Sierra Leone) countries in ECOWAS region for the period 1980 to 2017. The study uses data from the world development indicators and applies the panel data estimation technique (that included fixed and random effect and pooled OLS) to the data set. The results from the study shows a negative and significant relationship between exchange rate volatility and economic growth for Ghana and Nigeria whereas for The Gambia and Sierra Leone the relationship was negative but insignificant.

Similarly, in Nigeria Kenneth et al. (2016) 
examine the Impact of Exchange Rate Regimes on Economic Growth for the period 1970 to 2014. The study employed the Generalized Method of Moments (GMM) as the estimation strategy using data from the Central bank of Nigeria and the World Bank world development indicators. In addition, the study uses three period of exchange rate regimes which includes 1970 to 2014, 1970 to 1985 and 1985-2014. The study reveals that all the exchange rate regimes affected economic performance in Nigeria. Specifically, fixed exchange rates affect the performance of the Nigerian economy.

Using the Vector Error Correction Model (VECM) as the estimation strategy, Akinlo and Lawal (2015) examine the impact of exchange rate instabilities on industrial production in Nigeria. The period for the study was 1986 to 2010. The results from their study show the existence of a long run relationship among industrial production's index, exchange rate, inflation and money supply. Specifically, the study reveals that currency depreciation had no appreciable short-run effects on industrial production but had long-run positive effects on industrial production. Further, the study finds that variation in industrial production in Nigeria to a large extent is explained by the supply of money.

Using the ordinary least square regression as the estimation technique, Adeniran et al. (2014) examine the impact of exchange rate on economic growth in Nigeria for the period 1986 to 2013. The study uses data secondary data from Central Bank of Nigeria Statistical Bulletin of various issues. The study reveals a positive relationship between exchange rate and economic growth however the results was insignificant. In addition, the study finds a negative and significant relationship between inflation, interest rate and economic growth.

In a related study, Lotfalipour et al. (2013) investigate the effect of exchange rate on of manufacturing sectors investment in Iran spanning the period 1995 to 2009 . The study uses annual industry level data and employ the Generalized Method of Moments (GMM) as the estimation strategy. investment. The study reveals a negative and significant relationship between exchange rate and manufacturing sector investment.

Similarly, using the Generalized method of moments as the estimation technique and data from the world development indicators for 118 countries, Rodrik (2008) examine the effect of exchange rate on economic growth among two income group the poor and non-poor countries for the period 1950 to 2004. The study reveals that exchange rate has a positive and significant association with economic growth. In Canada, Baggs et al. (2009) investigate the effect of exchange rate on firm performance for the period 1986 to 1997. The study employs the ordinary least square regression as the estimation strategy. The results from their study reveals that exchange rate has a negative and significant effect on firm's performance. Specifically, the probability that Canadian firms survive from one period to the next period was found to be negatively related to exchange rate appreciation.

Caglayan and Muñoz Torres (2011) investigate the effect of exchange rate on fixed capital investment in Mexico spanning the period 1994 to 2002. The study employs the two-stage least square (2SLS) regression as the estimation technique. The study reveals that currency depreciation has an inverse relationship with fixed capital investment through the channel of exports or imports. Thus exchange rate is higher for industries that have low mark-up ratios and those in the non-durable goods sectors.

Specifically, on Ghana, studies on the effect of exchange rate on manufacturing firms' performance appears to be very scanty as most of the studies has focused on the effect of exchange rate (see for example Salifu et al., 2007; Nyarko et al., 2011; Mensah et al., 2013; Gyimah-Brempon \& Gyapong, 1993; Opoku-Afari et al., 2004; Alagidede \& Ibrahim, 2017; Bhattarai \& Armah, 2005; 
Kyereboah-Coleman \& Agyire-Tettey, 2008; Frimpong \& Adam, 2010; Insah \& Chiaraah, 2013) on economic growth, foreign direct investment, employment growth, capital inflows, trade balance, and exchange rate pass through effect. Notwithstanding from the empirical review and to the best of our knowledge we are aware of only two studies that examine the effect of exchange rate on manufacturing firms in Ghana with different focus (see for instance Abdul-Mumuni, 2019; Boateng, 2019).

Abdul-Mumuni (2019) examine the impact of exchange rate on the performance of manufacturing sector in Ghana for the period 1986 to 2013. The study uses annual time series data on manufacturing output as percentage of domestic product, exchange rates, imports, interest rates and foreign direct investment and applies the autoregressive distributed lag (ARDL) as the estimation technique. The study uses data from world bank world development indicators. The study reveals that the performance of manufacturing firms is positively related with exchange rate significantly.

In a related study Boateng (2019) investigate the effect of exchange rate on the financial performance of manufacturing firms in Ghana using Return on asset and equity as the dependent variable for the period 2009 to 2017. The study uses imports, foreign direct investment and nominal interest rate as control variables and applies the panel regression as the estimation. The results from the study show that the growth of manufacturing firms' financial performance is negatively associated with exchange rate. As can be seen from the empirical reviewed so far, most of the studies focused on the effect of exchange rate fluctuations on economic growth both outside and on Ghana (see for instance Salifu et al., 2007; Nyarko et al., 2011; Mensah et al., 2013; Gyimah-Brempon \& Gyapong, 1993; Opoku-Afari et al., 2004; Alagidede \& Ibrahim, 2017; Bhattarai \& Armah, 2005; Umaru et al., 2018; Kenneth et al., 2016;
Elbadawi et al., 2008). Specifically, the effect of exchange rate on manufacturing firms appears to be very scanty from the empirical review so far and the results has been inconclusive as regards the nexus between them. Therefore, the current study would add to the scanty literature on the effect of exchange rate fluctuations on manufacturing firms' performance in Ghana.

\section{Methodology}

This section presents the methodological framework adopted for the study and consists of three parts. Firstly, it presents the data type and sources followed by the model specification and finally the estimation strategy employed.

\subsection{Data type and source}

In achieving the objective of our study we relied on annual time series data from the annual reports of Bank of Ghana (2017), Ghana Statistical Service (2017), and World development indicators of the (WorldBank, 2019) spanning the period 1990 to 2018. The dependent variable is manufactured share of Gross Domestic Product and used as a proxy for manufacturing firm's performance. In addition, the independent variables include: exchange rate, inflation, monetary policy rate, investment, and trade openness. The period for the study was chosen due to data availability. Table 1 presents a brief summary of the definitions of the variable, measurement and data sources.

As regards a prior expectation of the variables, for exchange rate variable we expect a positive relationship between exchange rate and manufacturing firm's performance. Thus, a stronger exchange rate leads to the appreciation of the currency and this encourages importation of goods and services. This is because as our currency appreciates, manufacturing firms view imports of capital goods to be cheaper and hence take advantage in the acquisition of more capital goods which will affect their per- 
Table 1: Summary of variables, definitions and sources

\begin{tabular}{|c|c|c|}
\hline Variables & Definitions & Sources \\
\hline Manufacturing share of & It is expressed as a percentage of the country's gross domestic & Ghana Statisti- \\
\hline $\begin{array}{l}\text { Gross Domestic Product } \\
\text { (MGDP) }\end{array}$ & $\begin{array}{l}\text { product and represents the share of manufacturing in GDP } \\
\text { and used in this context as a proxy for manufacturing firms' } \\
\text { performance }\end{array}$ & cal Service, 2017 \\
\hline Exchange rate $(\mathrm{EXCR})$ & $\begin{array}{l}\text { Is defined as the value of one countries currency in terms of } \\
\text { the other countries currency and is measured as the exchange } \\
\text { rate of the Ghana Cedis for a unit of US dollars }\end{array}$ & $\begin{array}{l}\text { WorldBank, } \\
2019\end{array}$ \\
\hline Inflation (INFL) & $\begin{array}{l}\text { Is the increase in the general price of goods and services and } \\
\text { is measured using the Consumer Price Index (CPI) }\end{array}$ & $\begin{array}{l}\text { WorldBank, } \\
2019\end{array}$ \\
\hline $\begin{array}{l}\text { Monetary policy rate } \\
\text { (MPR) }\end{array}$ & $\begin{array}{l}\text { Represents the level of interest rates used by commercial banks } \\
\text { in the economy and is determined by the central bank of } \\
\text { Ghana. }\end{array}$ & $\begin{array}{l}\text { Bank of Ghana, } \\
2017\end{array}$ \\
\hline Trade openness (TOP) & $\begin{array}{l}\text { Is defined as the outward or inward orientation of a given } \\
\text { country's economy and is measured as trade as a percentage } \\
\text { of Gross domestic product (GDP) }\end{array}$ & $\begin{array}{l}\text { WorldBank, } \\
2019\end{array}$ \\
\hline Investment (INV) & $\begin{array}{l}\text { Is defined as the investment by firms other than their business } \\
\text { activities with the goal of making profit and is measured as } \\
\text { investment as a percentage of GDP }\end{array}$ & $\begin{array}{l}\text { WorldBank, } \\
2019\end{array}$ \\
\hline
\end{tabular}

formance positively. Also, the appreciation discourages exportation, and this is likely to affect the performance of manufacturing firms that exports most of their products as the home currency becomes much expensive as compared to their counterparts that sell their product in the home country. For inflation, we expect a positive or negative relationship with firm performance. This is so because as inflation increases the prices of manufacturing firms input increases and this is likely to affects their profit as price of output increase leading to a decline in demand for their product and vice versa.

Further, we expect a positive or negative relationship between monetary policy rate and manufacturing firm performance. This is because an increase in monetary policy rate leads to an increase in interest rates charged by commercial banks there by increasing the cost of borrowing by firms and this is likely to affect manufacturing sector performance and vice versa. Finally, regarding trade openness and investment we expect a positive relationship with manufacturing firm's performance.

\subsection{Model specification}

We follow previous studies by Mmaduabuchi and Ifeanyi (2014) and Abdul-Mumuni (2019) and specify the effect of exchange rate on manufacturing firm's performance and other control variables as follows:

$$
\begin{gathered}
M G D P_{t}=f(E X C R, I N F L, M P R, \\
T O P, I N V)+e_{t}
\end{gathered}
$$

In equation (1) $M G D P$ is the dependent variable which is the measure of manufacturing firms performance whereas the explanatory variables EXCR, INFL, MPR,TOP, INV represents exchange rate, inflation, monetary policy rat, trade openness, and investment respectively. The estimable form of equation (1) is thus specified as:

$$
\begin{gathered}
\ln M G D P_{t}=\beta_{0}+\beta_{1} \ln E X C R_{t}+ \\
\beta 2 \ln I N F L_{t}+\beta_{3} M P R_{t}+\beta_{4} \ln T O P_{t}+ \\
\beta_{5} I N V_{t}+\mu_{t}
\end{gathered}
$$

From equation (2) $\beta_{i}$ are the parameters to be estimated in the model, and $\mu_{t}$ represents the error term. Also, since we have taken the natural $\log$ of all the variables, coefficients 
are interpreted as elasticities. In addition $\beta_{1}, \beta_{2}, \beta_{3}, \beta_{4}$ and $\beta_{5}$ represent respective coefficient and elasticities of the independent variables as defined already.

\subsection{Estimation strategy}

The present study employs the autoregressive distributed lag (ARDL) model and bounds test for cointegration following Pesaran et al. (2001) and the error correction model (ECM) for the analysis. We employed the ARDL because of the relatively small number of observations 1990 to 2018. The ARDL is suitable for our study because it is able to make use of series that are strictly integrated of order zero, one or mix on the condition that the series are not integrated of order two or more (Baidoo \& Yusif, 2019). Further, according to Narayan (2005) the ARDL cointegration approach is superior in small samples compared to other single and multivariate cointegration techniques.

It worth highlighting that in using time series data, mostly the variables are likely to be non-stationary. Hence Newbold and Granger (1974) emphasized that using non-stationary variables in time series analysis may lead to biased and inconsistent estimates. Also it is likely to generate spurious regression not suitable for making analysis. In addressing this econometric concern, the study employed the Augmented Dickey-Fuller (ADF) test by Dickey and Fuller (1979, 1981)and Phillips and Perron test by Phillips and Perron (1988) are used for the unit root check. The ADF test is thus specified as:

$$
\triangle Y_{t}=\gamma_{0}+\delta Y_{t-1}+\gamma_{i} \sum_{i=1}^{p} \Delta y_{t-1}+\varepsilon_{t}
$$

The null hypothesis of the ADF and P-P test state that the series has a unit root. That is $H_{0}: \delta=0$ (indicate that there is the presence of unit root) as against the alternative hypothesis of $H_{1}: \delta<0$ (indicating that the series has no unit root). However, if the null hypothesis is rejected, it implies that the series are stationary.
After establishing the stationarity properties of the variables in equation (3), we first estimate the Error Correction model in an OLS form. The Autoregressive Distributed Lag Model (ARDL) is specified in equation (4) which provides both the short-and long run estimates in one single equation and the unit root test, and the cointegration test is then carried out. Also the ARDL bounds test specifies the functional relationship between manufacturing firm's performance, exchange rate, inflation, trade openness, investment, and monetary policy rate.

$$
\begin{gathered}
\triangle \ln M G D P_{t}=\alpha_{0}+\sum_{t=1}^{p} \beta_{1} \triangle \ln M G D P_{t-1} \\
+\sum_{t=i}^{p} \pi_{1} \triangle \ln E X R_{t-i}+\sum_{t=1}^{p} \eta_{1} \triangle \operatorname{lnINF_{t-i}} \\
+\sum_{t=1}^{p} \gamma_{1} \triangle \ln M P R_{t-i}+\sum_{t=1}^{p} \lambda_{1} \triangle \ln T O P_{t-i} \\
+\sum_{t=1}^{p} \varphi_{1} \triangle \ln I N V_{t-i}+\delta_{1} \ln M G D P_{t-1} \\
+\delta_{2} \ln E X R_{t-1}+\delta_{3} \ln I N F_{t-1}+ \\
\delta_{4} \ln M P R_{t-1}+\delta_{5} \ln T O P_{t-1} \\
+\delta_{6} \ln I N F_{t-1}+\varepsilon_{t}
\end{gathered}
$$

From equation (4), the $\triangle$ is the first difference operator. The parameters $\beta, \pi, \eta, \lambda$ and $\varphi$ in represent the dynamic coefficient in the short-run while the long-run multipliers are denoted by $\delta_{1}$ to $\delta_{6}$. In addition, the number of lags is denoted by $p$ whereas $\varepsilon_{t}$ is the stochastic error term which is identically and independent distributed.

Nonetheless, in order to have a valid longrun estimates, we follow Pesaran et al. (2001) and employ the F statistic test for joint significance of the lagged level variables incorporated in equation (4) which follows a non-standard distribution. Equation (5) and (6) represent the null and alternative hypothesis respectively. Equation (5) shows that there is no cointegration, thus, no long run relationship exists between the variables whereas equation (6) shows that there is no cointegration. Thus, no long run relationship 
exists between the variables. However, if the calculated F-statistic is more than the upper critical value, the null hypothesis of no long-run relationship is rejected otherwise it is accepted. However, if the F-statistic lies between the lower and the upper bound, the result is not concluded. The upper and lower bound critical values assume that all the variables are $I(0)$ and $I(1)$ respectively.

$$
\begin{aligned}
& H_{0}=\delta_{1}=\delta_{2}=\delta_{3}=\delta_{4}=\delta_{5}=\delta_{6}=0 \\
& H_{0} \neq \delta_{1} \neq \delta_{2} \neq \delta_{3} \neq \delta_{4} \neq \delta_{5} \neq \delta_{6} \neq 0
\end{aligned}
$$

Another important thing that we cannot overlook is the error correction model. The error correction model helps in reconciling the economic variables under consideration when there is a deviation in the behavior of the short-run and long-run variables. It simply measures the degree of deviation of the independent variables from equilibrium. The ECM model is thus specified;

$$
\begin{gathered}
\triangle Y_{t}=\alpha_{0}+\sum_{i=1}^{p} \beta_{i} \triangle Y_{t-i}+ \\
\sum_{i=1}^{q} \gamma_{i} \triangle X_{t-i}+\delta E C M_{t-i}+\varepsilon_{t}
\end{gathered}
$$

Where $Y$ represents the dependent variable with its lags and $X$ represents a list of independent variables with their lags, $\triangle$ denotes the first difference operator, whiles $\beta$ and $\gamma$ are the short run dynamic coefficients of the model. Further, $E C M_{t-i}$ is the error correction term which must have a negative sign and must be statistically significant with $\delta$ being its parameter indicating the speed of adjustment to long run equilibrium after a shock.

\section{Empirical Results and Discussion}

In this section we present the empirical results and discussions of the study. we first present the summary descriptive statistics of the variables. Secondly, we discuss the unit roots and the cointegration test results. Finally, we discuss the long- and short run estimates as well as the fitness of the model, stability and the reliability and stability tests.

\subsection{Descriptive statistics}

The study investigates the descriptive statistics of the variable included in the

\begin{tabular}{|c|c|c|c|c|c|}
\hline$\overline{\text { Variable }}$ & Obs. & Mean & S.D. & Min. & Max. \\
\hline $\operatorname{lnEXR}$ & 29 & 1.2555 & 1.3579 & 0.0326 & 5.5853 \\
\hline $\operatorname{lnMGDP}$ & 29 & 2.0186 & 0.2699 & 1.4701 & 2.3223 \\
\hline $\operatorname{lnINF}$ & 29 & 2.8407 & 0.5154 & 1.9637 & 4.0853 \\
\hline lnTrade & 29 & 4.2949 & 0.2593 & 3.7492 & 4.7540 \\
\hline MPR & 29 & 3.1235 & 0.3917 & 2.5260 & 3.8066 \\
\hline $\operatorname{lnINV}$ & 29 & 3.0087 & 0.2713 & 2.4650 & 3.3757 \\
\hline
\end{tabular}
model. The results are presented in Table 2. Exchange rate averaged 1.25 and ranges

Table 2: Descriptive statistics

between 0.03 and 5.58. Exchange rate also had a standard deviation of 1.36. The manufacturing firms' performance (Proxied by manufacturing share of GDP) variable also averaged 2.02 with a maximum value of 2.32 and a minimum value of 1.47 . The standard deviation of manufacturing firms' performance was also 0.27 . The Inflation variable also averaged 2.84 and falls between 4.08 and 1.96 over the sample period. Its deviation from the mean was also 0.51. Furthermore, trade openness also averaged 4.30 and fell within the ranges of 4.75 and 3.75 . Its deviation from the mean value was also recorded as 0.26 .

Also, monetary policy rate averaged 3.12 with a maximum and a minimum value of 3.806 and 2.53 respectively. It recorded a standard deviation of 0.40 . Finally, investment averaged 3.01 with a maximum and minimum value of 3.37 and 2.50 whereas the standard deviation is 0.30 accordingly. 
4.2 Unit root and cointegration test results

\subsubsection{Unit root test result}

The unit root test result from the ADF and P-P test are reported in Table 3. The results for both $\mathrm{ADF}$ and $\mathrm{PP}$ shows that exchange rate, monetary policy rate, and manufacturing sector value added variables in equation (3) are non-stationary at the levels but stationary at the first difference whereas oil price and inflation are all stationary at the levels. Specifically, the test for both ADF and $\mathrm{PP}$ shows that exchange rate, manufacturing sector share of GDP (which is used in this context as manufacturing sector performance), monetary policy rate, and trade openness in equation (3) are integrated of order one $I(1)$ and the remaining variables: Inflation and investment are integrated of order zero $I(0)$.

However, the result obtained from the ADF and PP test satisfy the use of the ARDL bounds test to ascertain the existence of a long-run relationship among the variables.

\subsubsection{Cointegration test results}

This section presents the results from the cointegration test results using the ARDL bounds test to ascertain the long run relationship for the dependent and independent variable are reported in Table 4.

From Table 4, $\mathrm{K}$ denotes the number of regressors or explanatory variables in the equation, ${ }^{* * *}$ represent rejection of the null hypothesis at $1 \%$ significance level. The results from Table 4 indicate that the F-statistic value of 12.97 is greater than the upper bound critical value of 4.68 at 1 percent significance level hence we reject the null hypothesis of no long run relationship among the dependent- and the independent variable in equation (3). It is therefore concluded the variables: manufacturing gross domestic product, exchange rate, inflation, oil price, monetary policy rate and wage rate are co-integrated and hence long run coefficient can be estimated.

\subsection{Estimated long- and short run re- sults using ARDL}

Table 5 presents the estimated long run regression results. The variable of interest is the exchange rate and the coefficient reveals a positive and significant relationship with manufacturing firm performance $(\ln M G D P)$ as expected.

Thus, the results indicate that the performance of manufacturing firms is negatively related with exchange rate. Specifically, this suggest that one percent increase in Ghana's exchange rate decreases manufacturing firm performance by 0.31 percent in Ghana all else being equal and is significant at one percent level of significant. This implies that depreciation of exchange rate results in a decrease in imported capital goods by manufacturing firms in Ghana. This is so because most of the manufacturing firms in Ghana rely on the import of capital goods and raw materials for their production and this will increase the cost of production and making locally produced goods less competitive than their imported counterparts. Also, as the exchange rate depreciate the capacity of firms to import these capital goods for their production declines hence affecting their performance. On the other hand, a depreciation of Ghana cedi increases the profit of export manufacturing firms in Ghana. This is because as our currency depreciate the price of exports becomes cheaper for foreign countries and hence turn to purchase more of our exports product thereby leading to an increase in manufacturing performance of export firms in Ghana as a result of an increase in profit from the sale made. Similarly, the over dependence of most of the manufacturing firms in Ghana on imported capital goods implies that a depreciating of the exchange rate would crowd out marginal investment due to high cost of investment. Our study is consistent with the results of 
Table 3: Unit root test results for $(\mathrm{ADF})$ and $(\mathrm{P}-\mathrm{P})$

\begin{tabular}{|c|c|c|c|c|c|c|c|c|}
\hline \multirow[t]{3}{*}{ Variable } & \multicolumn{4}{|c|}{ ADF } & \multicolumn{4}{|c|}{ P-P } \\
\hline & \multicolumn{2}{|c|}{ Levels } & \multicolumn{2}{|c|}{ 1st Difference } & \multicolumn{2}{|c|}{ Levels } & \multicolumn{2}{|c|}{ 1st Difference } \\
\hline & Constant & $\begin{array}{l}\text { Constant } \\
\text { with trend }\end{array}$ & Constant & $\begin{array}{l}\text { Constant } \\
\text { with trend }\end{array}$ & Constant & $\begin{array}{l}\text { Constant } \\
\text { with trend }\end{array}$ & Constant & $\begin{array}{l}\text { Constant } \\
\text { with trend }\end{array}$ \\
\hline $\operatorname{lnEXR}$ & -2.136 & -1.4534 & $-3.639 * * *$ & $-4.075^{* * *}$ & -2.036 & -1.516 & $-3.662^{* * *}$ & $-4.026^{* * *}$ \\
\hline $\operatorname{lnMGDP}$ & 0.978 & -0.839 & $-3.925 * * *$ & $-4.479 * * *$ & 0.797 & -0.888 & $-3.925 * * *$ & $-4.441 * * *$ \\
\hline $\operatorname{lnINF}$ & $-2.960 *$ & $-3.535^{*}$ & $-5.648 * * *$ & $-5.501 * * *$ & -2.912 & -3.319 & $-5.900 * * *$ & $-5.764 * * *$ \\
\hline lntrade & -2.449 & -2.134 & $-4.839 * * *$ & $-5.367 * * *$ & -2.449 & $-2.125^{*}$ & $-5.109 * * *$ & $-6.256 * * *$ \\
\hline LnINV & $-2.825^{*}$ & -2.728 & $-4.923 * * *$ & $-4.859 * * *$ & -2.679 & -2.572 & $-4.925^{* * *}$ & $-4.853^{* * *}$ \\
\hline LnMPR & -1.406 & -2.789 & $-3.647 * * *$ & $-3.587^{* * *}$ & -1.313 & -1.705 & $-4.472^{* * *}$ & $-4.398 * * *$ \\
\hline
\end{tabular}

Source: Authors' elaboration based on WorldBank (2019) data.
Note: ***,**, and * represent significance at $1 \%, 5 \%$ and $10 \%$ respectively.

Table 4: ARDL Bounds test for long run relationship

\begin{tabular}{lccc}
\hline F-statistic & $\mathrm{K}$ & $\begin{array}{c}\text { Lower bound } \\
\text { critical value }\end{array}$ & $\begin{array}{c}\text { Upper bound } \\
\text { critical value }\end{array}$ \\
\hline $12.97^{* * *}$ & 5 & 3.41 & 4.68 \\
\hline
\end{tabular}

Source: Authors' elaboration based on WorldBank (2019) data.

Table 5: Long-run estimations using the ARDL

\begin{tabular}{lccc}
\hline Regressor & Coefficient & $\begin{array}{c}\text { Standard } \\
\text { Error }\end{array}$ & T-Statistic \\
\hline LNEXR & $-0.3139^{* * *}$ & 0.0250 & -12.5404 \\
LNMPR & $-0.6181^{* * *}$ & 0.1147 & -5.3870 \\
LNINV & $0.4825^{* * *}$ & 0.1326 & 3.6381 \\
LNINF & $0.251^{* * *}$ & 0.0774 & 3.2407 \\
LNTRADE & $0.534^{* * *}$ & 0.1098 & 4.8703 \\
Constant & -0.7415 & 0.5347 & -1.3867 \\
\hline
\end{tabular}

Source: Authors' elaboration based on WorldBank (2019) data. Note: $* * *$ represent significant levels $1 \%$.

Boateng (2019),Lotfalipour et al. (2013) and Baggs et al. (2009) while contradicts with the results of Ayobami (2019), Williams (2018), Abdul-Mumuni (2019) and Akinlo and Lawal (2015). Regarding monetary policy rate, the study reveals a negative and significant relationship with manufacturing firms' performance at one percent level of significant. Thus all things being equal a one percent increase in monetary policy rate leads to a decrease in manufacturing firms' performance by 0.62 percent in Ghana. This means that when monetary policy rate increases the interest charged by commercial banks on loans also increases. However, as the cost of borrowing increases firms are unable able to take enough funds from banks to undertake their production activities. This is so because they have to repay back the loan taken with a higher amount of interest. Hence given that most of the manufacturing firms in Ghana rely on bank loan for their activities in the face of increasing cost of borrowing their growth(performance) would be affected.

Another important variable that affect the performance of manufacturing firms in Ghana is inflation. The study reveals that an increase in manufacturing firms' performance in Ghana is positively related with inflation. The coefficient of inflation is positive and significant at one percent level of significant. This means that a one percent increase in inflation results in improvement in manufacturing firms' performance by 0.25 percent. This implies that an increase in inflation serve as a cost to manufacturing firms' by increasing the input price of their products and all things being equal the increase in the input prices result to an increase in the output price of manufacturing firms thereby increasing their level of profit. This finding is consistent with study by Williams (2018).

With regard to trade openness, the study indicates a positive and significant relationship as expected with manufacturing firms' performance and is significant at one percent level of significant. Thus, the growth of manufacturing firms is positively related with trade openness. By implication a one percent increase in trade openness leads to an increase in manufacturing firms' performance by 0.53 percent. This implies that as manufacturing firms in Ghana engage in trade openness it provides new market 
opportunities for them which enhances their productivity, and innovation through competition domestically and externally. Therefore, trade openness is a requisite enabler for growth and hence this is vital for firm growth (performance). Hence as manufacturing firms take advantage of openness to trade their line of business expands and thereby leading to an increased in their performance

Finally, regarding investment variable as expected, the study indicates that investment has a positive coefficient and it significant at one percent level of significance. Thus, the performance of manufacturing firms in Ghana is positively related with investment. This implies that all things being equal a one percent increase in investment by firm leads to an in increase in manufacturing firm performance by 0.25 percent. This is so because manufacturing firms that engage in other forms of investment activities are likely to have enough capital requirement to undertake their activities and hence improvement in their performance.

The short run estimates are reported in Table 6 and the results are not statistically different from that obtained from the long run estimate. For instance, Inflation has a positive impact on manufacturing firms performance in Ghana both in the short and long-run. Also exchange rate has a negative effect on manufacturing firms' performance both in the short and long run. However, in the long run exchange rate was significant but in the short run exchange rate was insignificant.

Regarding monetary policy rate the study reveals a negative and significant effect on manufacturing firms' performance both in the short and long run estimates.

Contrary to the long run results, the coefficient of inflation rate is positive and statically significant at one percent level of significance. Thus, in the short run inflation affected manufacturing firms' performance in Ghana positively. Thus, in the short run inflation affected manufacturing
Table 6: Short-run estimations using the ARDL

\begin{tabular}{lccc}
\hline Regressor & Coefficient & $\begin{array}{c}\text { Standard } \\
\text { Error }\end{array}$ & t-stat. \\
\hline$\triangle \ln E X R$ & 0.0182 & 0.0903 & 0.2025 \\
$\triangle \ln E X R(-1)$ & -0.1482 & 0.0911 & -1.6262 \\
$\triangle \ln M P R$ & $-0.2557^{* * *}$ & 0.0610 & -4.1921 \\
$\triangle \ln I N V$ & 0.0370 & 0.0534 & 0.6927 \\
$\triangle \ln T R A D E$ & -0.0014 & 0.0812 & -0.0177 \\
$\triangle L I N F$ & 0.0252 & 0.0290 & 0.8689 \\
$\triangle \ln I N F(-1)$ & $0.0785^{* *}$ & 0.0329 & 2.3883 \\
ECM (-1) & $-0.4137^{* * *}$ & 0.0786 & -5.2593 \\
$\mathrm{R}^{2}$ & 0.9901 & & \\
AdjustedR 2 & 0.9829 & & \\
Durbin-Waston & 1.9983 & & \\
F-stat. & 136.8974 & & \\
Prob (F-stat.) & 0.000 & & \\
\hline \multicolumn{4}{l}{ Source: Authors' elaboration based on WorldBank (2019) data. }
\end{tabular}

firms performance in Ghana positively but insignificant. This is because increase in inflation results to a rise in input cost of production to firms and hence firms offset the rise in the cost of production by increasing the prices of their output thereby leading to an improvement in their performance Again in the short run, the coefficient of investment was positive and insignificant compared to the long run results where the coefficient was positive but significant at one percent level of significance. Finally, in the long run trade openness reveals a positive and significant effect on manufacturing firms' performance but in the short run estimates the coefficient of trade openness was negative and insignificant. This implies that in the short run the growth of manufacturing firms is negatively related with trade openness. Thus, one percent increase in trade openness decreases manufacturing firm performance in Ghana by 0.001 percent but insignificant. The error correction term is negative and significant which confirms the long run relationship between: exchange rate, manufacturing firm performance, crude oil price, wages, inflation, and monetary policy rate as well as a restoration to a long run equilibrium when there is a short run shock in any of the independent variables. Specifically, the error correction term, ECM (-1) of -0.41 shows that equilibrium in the long run is restored at a speed of approximately 41 percent after 
shock.

\subsection{Model diagnostic and reliability test results}

The validity of the estimates from the ARDL is dependent on the assumption that the model is free from any statistical problem. Therefore, Table 7 reports the diagnostic test results including: normality, serial correlation, heteroskedasticity, functional form, cumulative sum (CUSUM), and cumulative sum of squares (CUSUMQ).

The normality and serial correlation test con-

Table 7: Diagnostic test results

\begin{tabular}{lcc}
\hline Diagnostic test & $\begin{array}{c}\text { Test } \\
\text { Statistics }\end{array}$ & Prob. Value \\
\hline Normality & 1.2511 & 0.5350 \\
Serial correlation & 0.4913 & 0.6220 \\
Heteroskedasticity & 0.8801 & 0.5766 \\
Functional form & 1.1364 & 0.2749 \\
CUSUM & Stable & \\
CUSUMQ & Stable \\
\hline \multicolumn{2}{l}{ Source: Authors' elaboration based on WorldBank (2019) data. }
\end{tabular}

ducted using the Jarque-Bera test and the Breusch- Godfrey LM test respectively. Heteroskedasticity and functional test was done using Breusch-Pagan-Godfrey test and Ramsey reset test respectively. Finally, the stability of the model over the sample period is ascertained from the plots of CUSUM and CUSUMSQ.

From results Table 7 , it is evident that the estimated model is free from the abovementioned econometric problems since the probability values are greater than 0.05 . Also, the CUSUM and CUSUMQ graph in Figure 1 reveals that manufacturing firm performance over the sample period is stable. This is because the plots of the Cumulative sum and Cumulative sum of square (CUSUM and CUSUMQ) lie within the 5 percent critical bound.

\section{Conclusions and Policy Recommen- dations}

This paper has examined the effect of exchange rate fluctuation on manufacturing firms' performance in Ghana using annual time series data spanning the period 1990 to 2018. In achieving the objective of the study, bounds testing approach to cointegration within the framework of autoregressive distributed lag model (ARDL) and error correction model which are appropriate for relatively small sample size are used. The dependent variable is manufacturing firm performance (which was proxied by manufacturing share of GDP) and the independent variables include: exchange rate, inflation, monetary policy rate, and trade openness.

The short-run results reveal that exchange rate and trade openness was insignificant but had a negative effect on manufacturing firms' performance. Further, monetary policy rate has negative and significant association with manufacturing firms' performance whereas the result for inflation was positive and significant. Finally, the short run results a positive and insignificant relationship with manufacturing firm's performance. Regarding the long run results, the study reveals a positive and significant relationship for trade openness, inflation, and investment with manufacturing firms' performance. Also the study finds a negative relationship for exchange rate and monetary policy variables with manufacturing firms performance.

This study has some significant policy recommendations for developing countries especially Ghana. Firstly, given that exchange rate was negative and significant, the study recommends that Government and private partnership should ensure effective management of the exchange rate fluctuations in Ghana and also encouraging manufacturing firms to patronize locally made capital goods for their production in the face of a depreciating exchange rate. Secondly, following the positive and significant relationship between inflation and manufacturing firm's performance, it is recommended that in the face 

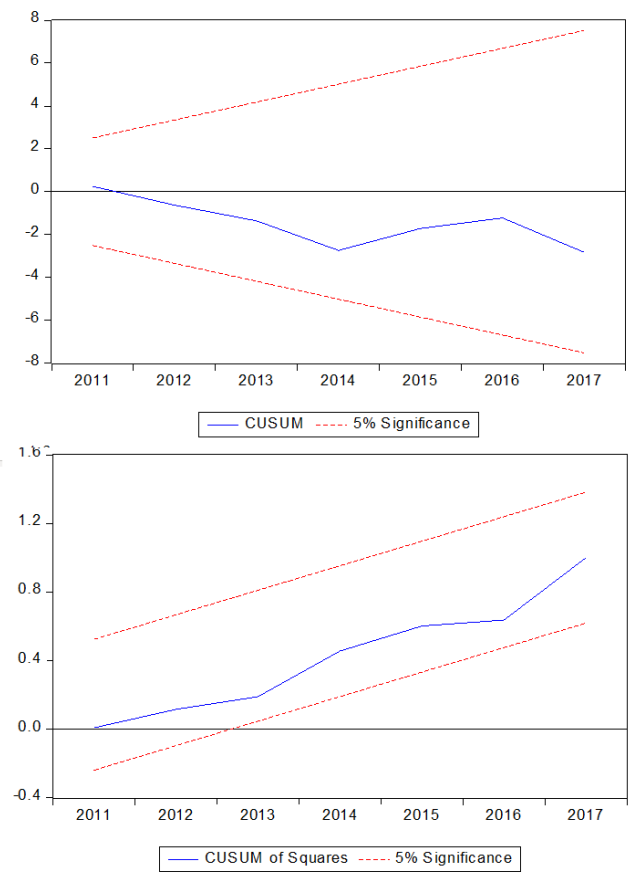

Figure 1: Plots of CUSUM and CUSUMQ

of increasing inflation in the country Government and monetary authorities should provide subsidies for input of manufacturing products so as to reduce their cost of production and sell at slightly higher price whiles retaining their profit without necessarily passing on their high cost of production to consumers at a higher price which might also deter consumers from purchasing their products. Thirdly, for trade openness and manufacturing firms' performance, the study recommends that since trade openness is an enabler of growth, manufacturing firms in Ghana should engage in trade openness to take advantage of new market opportunities and innovation which would make them competitive domestically and externally hence increasing their growth (performance). Finally, the study recommends that the central bank of Ghana (monetary authorities) should reduce interest rate which will increase investment by firms following the positive relationship between investment and manufacturing firms' performance.

\section{References}

Abdul-Mumuni, A. (2019). Exchange rate variability and manufacturing sector performance in Ghana: Evidence from cointegration analysis. International Economics and Business, 2(1), 1-14. doi:10.5296/ieb.v2i1.9626

Adeniran, J., Yusuf, S., \& Adeyemi, O. A. (2014). The impact of exchange rate fluctuation on the Nigerian economic growth: An empirical investigation. International Journal of Academic Research in Business and Social Sciences, 4(8), 224-233. doi:10.6007/IJARBSS/v4-i8/1091

Aizenman, J., \& Marion, N. P. (1999). Uncertainty and the disappearance of international credit (NBER Working Paper No. 7389). National Bureau of Economic Research. doi:10.3386/w7389

Akinlo, O. O., \& Lawal, A. Q. (2015). Impact of exchange rate on industrial production in Nigeria 1986-2010. International Business and Management, 10(1), 104-110. doi:10.3968/6046

Alagidede, P., \& Ibrahim, M. (2017). On the causes and effects of exchange rate volatility on economic growth: Evidence from Ghana. Journal of African Business, 18(2), 169-193. doi:10.1080/15228916.2017.1247330

Ayobami, O. T. (2019). Exchange rate volatility and the performance of manufacturing sector in Nigeria (1981-2016). African Journal of Economic Review, 7, 27-40. https://www.ajol.info/index 
.php/ajer/article/view/188375.

Baggs, J., Beaulieu, E., \& Fung, L. (2009). Firm survival, performance, and the exchange rate. Canadian Journal of Economics/Revue canadienne d'économique, 42(2), 393-421. doi:10.1111/j.1540-5982.2009.01513.x

Bahmani-Oskooee, M., \& Miteza, I. (2003). Are devaluations expansionary or contractionary? A survey article. Economic Issues Journal Articles, 8(2), 1-28. Retrieved from https://EconPapers .repec.org/RePEc: eis : articl:203bahmani

Baidoo, S., \& Yusif, H. (2019). Does interest rate influence demand for money? an empirical evidence from ghana. Economics Literature, 1(1), 24-36. doi:10.22440/elit.1.1.2

Bank of Ghana. (2017). Bank of ghana annual reports (Annual Report No. 2018). Bank of Ghana. https://www.bog.gov.gh/wp-content/ uploads/2019/07/AnnRep-2018.pdf.

Bhattarai, K., \& Armah, M. K. (2005). The effects of exchange rate on the trade balance in ghana: Evidence from cointegration analysis. Business School, University of Hull Cottingham.

Boateng, J. O. (2019). The impact of exchange rate fluctuations on firms financial performance: A case study of some selected manufacturing firms in ghana (Doctoral dissertation, University of Ghana). http://ugspace.ug.edu.gh/handle/ $123456789 / 32766$.

Caglayan, M., \& Muñoz Torres, R. (2011). The effect of the exchange rates on investment in Mexican manufacturing industry. Open Economies Review, 22(4), 669-683. doi:10.1007/s11079-0109166-0

Dickey, D. A., \& Fuller, W. A. (1979). Distribution of the estimators for autoregressive time series with a unit root. Journal of the American Statistical Association, 74(366a), 427-431. doi:10.1080/01621459.1979.10482531

Dickey, D. A., \& Fuller, W. A. (1981). Likelihood ratio statistics for autoregressive time series with a unit root. Econometrica, 49(4), 1057-1072. doi: $10.2307 / 1912517$

Elbadawi, I. A., Kaltani, L., \& Schmidt-Hebbel, K. (2008). Foreign aid, the real exchange rate, and economic growth in the aftermath of civil wars. The World Bank Economic Review, 22(1), 113140. doi: $10.2307 / 40282266$

Frimpong, S., \& Adam, A. M. (2010). Exchange rate pass-through in Ghana. International Business Research, 3(2), 186-192. https://pdfs.semanticscholar.org/d2d9/ c68e78cb0572d35dd7b25b742cb9d2438669.pdf.

Ghana Statistical Service. (2017). Rebased 2013-2018 annual gross domestic product (National Accounts Statistics (various issues)). Ghana Statistical Service. https://www.statsghana.gov.gh/gssmain/ fileUpload/National\%20Accounts/Annual_2013 _2018_GDP_April\%202019\%20Edition.pdf.

Gyimah-Brempon, K., \& Gyapong, A. O. (1993). Exchange rate distortion and economic growth in ghana. International Economic Journal, 7(4), 59-74. doi:10.1080/10168739300000014

Insah, B., \& Chiaraah, A. (2013). Sources of real exchange rate volatility in the Ghanaian economy. Journal of Economics and International Finance, 5(6), 232-238. doi:10.5897/JEIF2013.0517

Kenneth, O. O., Jonathan, O. O., \& Kenneth, U. N. (2016). The impact of exchange rate regimes on economic growth in nigeria. Journal of Economics and Sustainable Development, 7(12), 115-127. https://pdfs.semanticscholar.org/d91c/ $7 f$ ee34038bb0b7e1b238ed7d22b3ebb08cfa.pdf.

Kyereboah-Coleman, A., \& Agyire-Tettey, K. (2008). Effect of exchange-rate volatility on foreign direct investment in sub-saharan africa: The case of ghana. The Journal of Risk Finance, 9(1), 52-70. doi:10.1108/15265940810842410

Lotfalipour, M. R., Ashena, M., \& Zabihi, M. (2013). Exchange Rate Impacts on Investment of Manufacturing Sectors in Iran. Business and Economic Research, 3(2), 12-22. doi:10.5296/ber.v3i2.3716

Mensah, M., Awunyo-Vitor, D., \& Asare-Menako, H. (2013). Exchange rate volatility and employment growth in ghana's manufacturing sector. International Journal of Business and Social Science, 4(4), 225-232. http://ijbssnet.com/journals/ Vol_4_No_4_April_2013/24.pdf.

Mmaduabuchi, E. F., \& Ifeanyi, A. E. (2014). Exchange rate and manufacturing performance in Nigeria. Journal of Empirical Economics, 3(6), 352-361. https://ideas.repec.org/a/ rss/jnljee/v3i6p3.html.

Narayan, P. K. (2005). The saving and investment nexus for China: evidence from cointegration tests. Applied Economics, 37(17), 19791990. doi:10.1080/00036840500278103

Newbold, P., \& Granger, C. (1974). Experience with forecasting univariate time series and the combination of forecasts. Journal of the Royal Statistical Society: Series A (General), 137(2), 131146. doi: $10.2307 / 2344546$

Nyarko, P. A., Nketiah-Amponsah, E., \& Barnor, C. (2011). Effects of exchange rate regimes on FDI inflows in Ghana. International Journal of Economics and Finance, 3(3), 277-286. doi:10.5539/ijef.v3n3p277

Odili, O. (2014). Exchange rate and balance of payment: An autoregressive distributed lag (ardl) econometric investigation on nigeria. IOSR Journal of Economics and Finance (IOSR-JEF, 4(6), 21-30. https://pdfs.semanticscholar.org/08d0/ 249569e4e1209a965b267c817a568d7dd3d0b.pdf] .

Ofori, I. K., Obeng, C. K., \& Armah, M. K. (2018). Exchange rate volatility and tax revenue: Evidence from ghana. Cogent Economics \& Finance, 6(1), 1537822. doi: $10.1080 / 23322039.2018 .1537822$

Opoku-Afari, M., Morissey, O., \& Lloyd, T. (2004). Real exchange rate response to capital inflows: 
A dynamic analysis for ghana (CREDIT Research Paper No. 04/12). Nottingham: The University of Nottingham, Centre for Research in Economic Development and International Trade (CREDIT). http://hdl.handle.net/ 10419/65444.

Pesaran, M. H., Shin, Y., \& Smith, R. J. (2001). Bounds testing approaches to the analysis of level relationships. Journal of Applied Econometrics, 16(3), 289-326. doi:10.1002/jae.616

Phillips, P. C. B., \& Perron, P. (1988). Testing for a unit root in time series regression. Biometrika, 75 (2), 335-346. doi:10.1093/biomet/75.2.335

Rodrik, D. (2008). The real exchange rate and economic growth. Brookings papers on economic activity, 2008(2), 365-412. doi:10.1353/eca.0.0020

Salifu, Z., Osei, K. A., \& Adjasi, C. K. (2007). Foreign exchange risk exposure of listed companies in ghana. The Journal of Risk Finance, 8(4), 380-393. doi:10.1108/15265940710777324

Todaro, M. P., \& Smith, S. C. (2008). Economic development, 10th edition. Pearson.

Umaru, H., A., A. N., \& Davies, N. O. (2018, October). The effects of exchange rate volatility on economic growth of West African Englishspeaking countries. International Journal of Academic Research in Accounting, Finance and Management Sciences, 8(4), 131-143. Retrieved from http://hrmars.com/hrmars_papers/ The_Effects_of_Exchange_Rate_Volatility_on Economic_Growth_of_West_African_English -Speaking_Countries.pdf

Williams, H. T. (2018). An empirical investigation of the impact of exchange rate fluctuations on the performance of selected listed firms in nigeria. ournal of Business Management and Economic Research, 2(3), 1-10. doi:10.29226/TR1001.2018.22

WorldBank. (2019). World development indicators. http://datatopics.worldbank.org/world -development-indicators/. Washington DC: World Bank. 